\title{
The Impact of Child Soldiers on \\ Rebel Groups' Fighting Capacities
}

\author{
ROOS HAER
}

University of Konstanz

AND

TOBIAS BÖHMELT

University of Essex \& ETH Zurich

\begin{abstract}
Several rebel groups actively recruit children to serve among their ranks. While this constitutes one of the most egregious violations of children's rights, it remains unclear what impact recruited children have on the fighting capacities of these armed groups. The existing research suggests that, on the one hand, armed groups drafting children might also be militarily effective, since it is cheaper to provide for children, they are more obedient and aggressive than adults, and easily manipulable. On the other hand, children may negatively affect rebel groups' fighting capacities as they are less proficient combatants than adults and often difficult to control. We add to this debate by systematically analyzing the quantitative evidence on the impact of child soldiers on rebel groups' fighting capacities. Based on the analysis of newly compiled data on child recruitment by rebel groups between 1989 and 2010, our analyses show that children may actually increase rebel groups' fighting capacities. That said, rebels' ability to procure arms and the access to resources seem more important determinants of fighting capacity. The authors discuss these findings in light of policy implications and avenues for future research.
\end{abstract}

Keywords: child soldiers, fighting capacity, rebel groups, violence

Corresponding author: Roos.vanderHaer@uni-konstanz.de

University of Konstanz

Room C 306

P.O. Box 90

D-78457 Konstanz

Tel: +49 [0] $753188-4804$

Replication data: the dataset, codebook, replication instructions for the empirical analysis, and appendices of this article can be found at the corresponding author's website: http://www.polver.uni-konstanz.de/en/holzinger/team/roos-van-der-haer/publications/.

Acknowledgements: We are grateful for constructive comments, general support, or assistance with the data collection by Lilli Banholzer, Lena Garrettson, Valentin Gold, Katharina Holzinger, Daniela Kromrey, Caitlin Talmadge, Clayton Thyne, and Thanakon Tiwawong. We also thank the anonymous reviewers and the journal's editor, Glenn Palmer, for valuable input. 


\section{Introduction}

Governments, militias, and especially rebel organizations have actively and in large numbers recruited children throughout the world (Gates and Reich 2010; Lasley and Thyne 2014). ${ }^{1}$ Although child soldiering is not a new phenomenon, it has turned (again) into a more common practice since the end of World War II, while children's contribution has changed fundamentally as well (Brett and McCallin 1998). With an increase in internal conflicts and changes in warfare (Gates, Hegre, and Strand 2007), children as the targets of violence and, most importantly for this study, also as members and even combatants of rebel groups have become more central to the way wars are fought: their involvement in today's conflicts can no longer be classified as passive (London 2007). Although it is unclear how many children are currently involved in armed groups, the fact that children (have to) actively participate (even as fighters) in military campaigns constitutes one of the most serious violations of children's rights (e.g., Tynes 2011: 2; Brett and McCallin 1996; Høiskar 2001). ${ }^{2}$

While the scholarly research on this phenomenon is substantially growing, activists, think tanks, or civil society groups have conducted most of the earlier work (see Achvarina and Reich 2010). The existing academic studies on child soldiering - despite being few in number and largely focusing on single countries or being of a descriptive nature - have nonetheless revealed crucial insights. For example, given a predominant focus on child soldier recruitment, scholars looked at the "general systemic factors" such as globalization, the development of small weapons, or legitimacy concerns (e.g., Honawa 2006; Singer 2006, 2010; Lasley and Thyne 2014). Others examined why children would join armed organizations, i.e., the so-called supply side of child soldier recruitment. Tynes (2011: 93), for instance, claims that children might join armed groups as a way out of poverty.

Building on this literature, we seek to contribute to the existing research by studying another important, but somewhat neglected linkage: the relationship between child

\footnotetext{
${ }^{1}$ Following UNICEF (2007), we define child soldiers as "any person below 18 years of age who has been recruited or used by an armed force or armed group." This 18-years threshold has not only been adopted in the optional protocol to the convention on the Rights of the Child on the Involvement of Children in Armed Conflict (UN 2000: Art 1), but also as international law in 2000. Even before that, one of the most influential reports on children in conflict - the UN Machel Report (1996) - and the UN 1989 Convention on the Rights of the Child used the definition of 18 years of age. We recognize, however, that this threshold is not without controversy (e.g., Tynes 2011; Tynes and Early 2011).

${ }^{2}$ UNICEF (2002) estimates that ca. 300,000 children were actively involved as fighters in at least 45 conflict zones between 1988 and 2002 (see also, e.g., Achvarina and Reich 2006; Høiskar 2001). Tynes and Early (2011: 3) report a similar figure for the period between 1987 and 2007. Note, however, that other sources like the Human Security Report (2005) question this number.
} 
recruitment and the fighting capacity of rebel groups. ${ }^{3}$ Put differently, is it the case that armed groups recruiting many children are more military effective, i.e., do these rebel groups have a higher fighting capacity relative to the government? ${ }^{4}$ Anecdotal evidence for this possible relationship is given by the Revolutionary Armed Forces of Colombia (FARC), which named their child soldiers "little bees," because they can "sting" their enemies before these know they are under attack (Singer 2006). Moreover, Kaplan (2005) states that children can be daring and tenacious in combat, particularly when under the influence of drugs or when compelled by political or religious zeal. Child units can greatly add to confusion on battlefields, slowing opposing forces' progress. Yet, the relationship between child soldiers in rebel groups and their military effectiveness has not yet been explored systematically and rigorous empirical research remains scarce.

The existing work, although having the somewhat different focus on the recruitment of children, points to contradictory answers. On one hand, the presumed military effectiveness of child soldiers stems from their characteristics: they can provide logistical support, it is cheaper to provide for them, they are more obedient, and more easily susceptible than mature combatants. Also, children socialized into rebel groups acquire the norms and values of their militant environment and become significantly more aggressive than their grown-up counterparts (e.g., Andvig and Gates 2010; Schauer and Elbert 2010). On the other hand, adolescent soldiers may negatively affect rebel groups' fighting capacities as children are less proficient fighters than adult combatants and they are more difficult to control.

We add to this debate by systematically analyzing the quantitative relationship between child recruitment and the rebel groups' fighting capacities. To this end, we first give a brief overview of the existent literature on child soldier recruitment and elaborate on our definition of military effectiveness, i.e., fighting capacity. We then develop the theoretical arguments on the impact of rebel child soldiers on their groups' fighting capacity. Afterwards, we describe the research design and, based on newly compiled data on child recruitment by rebel groups between 1989 and 2010, we use probit models to analyze the data. Our results show that child soldiers may actually increase rebel groups' fighting capacities. That said, rebels' ability to procure arms and the access to resources, i.e., some of the variables we include as alternative determinants of fighting capacity, seem more important determinants. We finish this study

\footnotetext{
${ }^{3}$ While rebel groups are not the only military organizations that recruit children (Gates and Reich 2010), we focus on these groups as Tynes and Early (2011: 4) argue that rebel groups have "fewer constraints" in and "more to gain" by using child soldiers than governments.

${ }^{4}$ As elaborated more thoroughly below, we understand a rebel group's fighting capacity as the ability to employ its forces to destroy the government's military while preserving its own troops (Dupuy 1992: 71ff; Biddle, 2004: 6; Stanley and Brooks 2007).
} 
with a discussion of our work and its implications, and also suggest avenues for further research.

Examining the impact of child soldiers on armed groups' fighting capacities may not only contribute to the on-going debate about what makes children attractive recruits, but additionally provide arguments against the use of adolescent soldiers in conflict, which has inherently short and long-term implications for the development of children in affected countries (Singer 2006).

\section{The Recruitment of Child Soldiers in Armed Conflicts: A Brief Overview}

Children recurited for armed groups perform a range of tasks, e.g., "participation in combat, laying mines and explosives, scouting, spying, acting as decoys, couriers or guards, training, drill or other preparations, and logistics and support functions such as portering, cooking and domestic labour" (Coalition to Stop the Use of Child Soldiers 2010). In light of this, the academic literature on child soldier usage can generally be categorized along two interrelated, albeit different streams (see also Beber and Blattman 2013; Tynes 2011). The first one focuses on the general or systemic factors to explain the rise in child soldier usage since the end of World War II. ${ }^{5}$ Honwana (2006), for example, argues that inequalities increased with globalization, which weakened social norms and value systems to protect children from recruitment. This, in turn, led to a rise in the number of children used in armed conflict. Additionally, Dallaire (2011) highlights the sheer abundance of young recruits, as overpopulation made children cheap or renewable resources as influences of child soldiering. Furthermore, Singer $(2006 ; 2010)$ stresses the fact that weapons have been simplified and became lighter in the recent past, which makes them usable for children.

In this context, scholars emphasized that these general systematic factors have facilitated the "transformation" of children into active fighters who are then just as militarily effective as adults. In turn, children may therefore be recruited more often than in earlier periods of time (Cohn and Goodwill-Gill 2003). Put differently, while children may be recruited for secondary support functions (e.g., Dickson-Gõmez 2002; Gates and Reich 2010), e.g., logistics, carrying goods, cooking, or intelligence gathering, some of these systematic factors

\footnotetext{
${ }^{5}$ As indicated above, child soldiering is not a new phenomenon. On the contrary, in Modern European societies, it was formerly commonplace for children to be enrolled in field regiments. However, since the end of World War II and perhaps also since the end of the Cold War, the number of children used and participating in conflicts has significantly increased (e.g., Rosen 2005; Singer 2006; 2010; Vautravers 2008).
} 
make it more likely that children take a more active role in combat. Singer (2006), for instance, claims that most child soldiers do in fact participate in combat actively rather than fulfilling secondary functions. This is also confirmed by a UNICEF (2003) survey, which indicates that more than 90 percent of the children had served in combat rather than in more supportive functions. Individual research on armed groups active in Liberia, Colombia, or the Central African Republic confirms this assessment (Human Rights Watch 2003; International Labor Office 2003; IRIN 2003).

The second stream mainly studies the motivation of children to join armed groups, i.e., the supply side of child soldering. The most prominent influences in this context pertain to the lack of education and future perspectives, as well as poverty and starvation (e.g., Tynes 2011: 93). Other identified supply-side variables are the social pressure exercised by family and friends due to religious or ethnic identification, the desire to protect the home village and community, or the pursuit of "adventures and excitement" (Cohn and Goodwill-Gill 2003; Brett and Specht 2004; Achvarina and Reich 2010; Andvig and Gates 2010; Becker 2010; and Singer 2006; 2010).

Against this background, a third stream recently emerged as a response to the inability of the first two to explain variation in child soldier usage across warring parties active in the same period of time and the same country (or a common region) (Beber and Blattman 2013). To elucidate this variation, scholars now increasingly focus on the so-called demand side of child soldier recruitment, i.e., what are the incentives of armed groups to recruit children? One important and often mentioned reason might be that rebel organizations draft children, because they improve the military effectiveness or fighting capacity of armed groups. Beber and Blattman (2013: 68) emphasize, for example, that "children will be recruited if they are more effective fighters than we suppose" (see also Tynes 2011; Tynes and Early 2011).

\section{Military Effectiveness: The Role of Fighting Capacity}

In the words of Biddle and Long (2004: 527), "military effectiveness can be defined in a variety of ways: see, for example, Brooks (2003) and Biddle (2004: chap. 1). This definitional complexity stems in part from the many tasks militaries are asked to perform." That said, the arguably most detailed and disaggregated approach to this concept is given by Millett, Murray, and Watman (1986: 37; see also 1988). These scholars define military effectiveness as "the process by which armed forces convert resources into fighting power" (see also Rosen 1995: 6). In turn, Millett, Murray, and Watman (1986: 38ff; see also 1988) distinguish between political, strategic, operational, and tactical effectiveness. Specifically, 
the first type of military effectiveness pertains to the ability of the military leadership to secure the cooperation from the political elite. The second type focuses on the military's ability to effectively pursue those goals of a military campaign that the political leadership stated in the first place. The third type refers to the military's ability to achieve strategic war objects via the development and use of concepts and doctrines. Finally, tactical effectiveness captures the effectiveness of small combat units and their employed techniques to pursue operational goals.

Military effectiveness is thus a multidimensional concept that focuses primarily on the achievement of prescribed goals at various levels of military activity. A corresponding theoretical empirical focus is warranted, but unfortunately not possible due to the lack of coding in our data that we describe below. Instead, for the remainder of this article, we follow Biddle and Long (2004: 528), "by focusing on one especially important military function," i.e., "the critical military function of destroying hostile forces while preserving one's own." In other words, we understand a rebel group's military effectiveness in terms of its fighting capacity, which is the ability to employ its forces to destroy the government's military while preserving its own troops - holding situational or environmental factors, force size, and weapon technology constant (Dupuy 1992: 71ff; Biddle 2004: 6; Stanley and Brooks 2007; see also, e.g., Rosen 1995; Pollack 2002; Brooks 2003; Desch 2008; Talmadge 2013: 185f).

To this end, we focus on the core goal of any military organization. Again, while this mirrors in particular Biddle and Long (2004; see also Biddle 2004: 6), this treatment is also consistent with the broader definition by Millett, Murray, and Watman (1986: 37), i.e., military effectiveness is "the process by which armed forces convert resources into fighting power." While this focus does not necessarily require that all recruited children have to perform combat functions (see, e.g., Millett, Murray, and Watman 1986), the shortcoming of this approach is that our empirical results only apply to this type military effectiveness. Other aspects of military effectiveness, particularly those disaggregated elements highlighted at the political, strategic, or operational level by Millett, Murray, and Watman $(1986,1988)$ are not addressed by the following work.

\section{Child Soldiers and Rebel Groups' Fighting Capacities: Theoretical Arguments}

The literature on child soldiers lacks a systematic empirical analysis of whether child soldiers are militarily effective or not, but we can derive three interrelated, yet different theoretical reasons for why rebel groups recruiting children have a higher level of fighting capacity. First, children may possess certain characteristics that can lead to a higher fighting capacity 
of rebel groups drafting them, and, therefore, these characteristics make them attractive for conscription in the first place. What makes children equally strong, or perhaps even more effective fighters in comparison to adult combatants, is that the former are said to be more malleable, adaptable, and obedient. Schauer and Elbert (2010: 316f), for instance, point out that "children might be told and believe that they have to 'stand up' against an enemy, who would otherwise kill them or hurt their families; they tend to trust and obey caretakers' and families' or key community leaders' judgment on this.” Reiter and Stam (2002: 58ff) also emphasize such psychological factors in the more general literature on military effectiveness. In turn, children are more easily influenceable, which makes them easier to control and retain (e.g., Gutiérrez Sanín 2010; Beber and Blattman 2013). These characteristics not only facilitate their recruitment, but also are likely to lead to a higher fighting capacity of the rebel group. This is especially important for armed groups without a broad membership or support base (Woods 1993; Brett, McCallin, and O’Shea 1996; Singer 2006; Wessells 2006; Tynes and Early 2011; Beber and Blattman 2013).

Second, military effectiveness in the form of fighting capacity is not exclusively driven by the number of active combatants (Millet, Murray, and Watman 1986; 1988). The proper execution of logistical and support functions also affects the overall performance of an armed group. Reiter and Stam (1998: 261) argue that it is of vital importance that military organizations are able to master "tasks such as general planning, providing logistical support, gathering intelligence, preparing appropriate works such as entrenchments and ramparts, training, and achieving tactical surprise." As indicated above, child soldiers frequently fulfill many of these logistics and support functions (Dickson-Gõmez 2002; Gates and Reich 2010; see also, e.g., Singer 2006). Consequently, even if child soldiers are not directly active in combat, they may still strengthen the fighting capacity of an armed group: their logistical support indirectly improves the fighting capacity and, additionally, other members of this organization can then be allocated to combat tasks as they are not committed to logistical and support functions.

Third, regardless of their function as active combatants or logistical supporters, child soldiers are also said to be more loyal, committed, and less likely to desert than adults (Gates and Reich 2010). Children might perceive their membership in rebel groups as their occupation and also see them as their primary social network - equal to that of a family or village community (Hazen 2005: 4): there are numerous cases where former child soldiers returned to their fighting fraction "out of a sense of family, loyalty, and security" rather than for pecuniary rewards. Particularly the importance of this argument on loyalty and 
commitment enjoys wide support in the more general military effectiveness literature. Reiter and Stam (2002: 60ff; see also 1998) and Biddle and Long (2004: 530f), for example, theoretically argue and empirically demonstrate that soldiers with a higher commitment to their leaders are the most effective fighters.

Finally, children may be more likely to take risks, can deal more easily with the dangers in battle, and often feel that they are invulnerable (Brett and Specht 2004). More specifically, Singer (2006: 80f) claims that children are unable to fully comprehend the risks and consequences of their behavior and have a so-called "underdeveloped death concept." This might turn children into fierce fighters who could be even deadlier than adult combatants. Similarly, children are more likely to perpetrate a more diverse set of violent actions, e.g., sexual violence, massacres, physical assault, or mutilations (Hecker and Haer forthcoming). Psychological research also emphasizes that child soldiers show more aggressiveness than adult combatants as they perceive violence as something positive and fascinating (Wessels 2006; Schauer and Elbert 2010).

In light of all those arguments, our first hypothesis suggests that recruiting children may increase a rebel group's fighting capacity - irrespective of their function in that group. Children might here not necessarily be more effective than adults, but they could still improve rebel fighting capacity relative to not recruiting child soldiers at all. As a US military officer stated: adolescent fighters are nearly "as good as conscript-drafted Americans or Europeans in the use of NATO tactics" (Singer 2006: 87).

However, several other studies argue that adolescent soldiers may be costly for the group, i.e., negatively influence rebel groups' fighting capacities as compared to not recruiting child soldiers at all. First, Gates (2011: 32) points out that "extremely few 12-year-olds possess the strength, endurance, and agility of a well-trained 22-year-old male soldier.” Biddle and Long (2004: 528) also emphasize the importance of physical strength, which children obviously do not possess.

Second, despite the development of small weapons (Singer 2006; 2010), rebel groups still have to invest resources for the training of children either in relation to military tactics (combat role) or their logistical support function. For example, since children are less likely than adults to have fighting skills and to understand military tactics in the first place. They do not know when to hide or to attack and they might take unnecessary risks, which increases the probability of being killed by the opponent's forces (Singer 2006). The broader literature on military effectiveness sees these strategies and tactical skills - and an understanding 
thereof - as critical for military success, though (e.g., English and Gudmundsson 1994: 15ff Reiter and Stam 2002; Biddle 2004: 38f; Biddle and Long 2004).

Third, and derived from the previous point, child soldiers may be more malleable, obedient, or influenceable, but rebel groups still have to invest more efforts and resources for their socialization process than in the case of adults (Gates and Reich 2010). As a commander of a Myanmar armed group stated, "child soldiers are still children, and that they often misbehave, are unruly, and require frequent scolding, as young boys usually do" (Images Asia 1999: 9). Consequently, without a thorough and perhaps rather costly socialization process in the first place, which would not (always) be necessary in the case of adult recruitment, children may be less likely to perform their tasks in an armed group and are, in fact, more likely to desert or run out of control (Gutiérrez Sanín 2010; Beber and Blattman 2013). Several reports provide accounts of out-of-control adolescent fighters. Recounting his observations in Sierra Leone in 1999, Junger (2000), for instance, writes that "[t]eenage soldiers $[\ldots]$ rounded up entire neighborhoods and machine-gunned them or burned them alive in their homes."

To recap, most studies on child soldiering focused on why child soldiering occurs in the first place. Few studies examined the consequences of child soldiering, which is related to the demand side of this phenomenon. One aspect of this pertains to how children might influence the military effectiveness of rebel groups. While there are arguments for a positive influence, other scholars emphasized the potential problems related to their recruitment: child combatants are more likely than adults to run out of control and desert, they often lack strategic and tactical skills and would require a costly socialization process, and they simply lack the physical strength necessary for combat. Our second, alternative hypothesis therefore states that all these factors might, in turn, lead to the outcome that child soldiering negatively influences rebel groups' military effectiveness. In the following, we use new data to shed empirical light on how and to what extent child soldiers affect rebels' fighting capacity by quantitatively examining rebel organizations at the group-level.

\section{Research Design}

Data

We compiled new data on child soldiers in rebel groups between 1989 and 2010. The basis for our data collection and the succeeding analyses is the Non-State Actor (NSA) dataset by Cunningham, Gleditsch, and Salehyan $(2009 ; 2013)$. These data are an expansion of the Uppsala Armed Conflict Data (Gleditsch et al. 2002) and provide accurate information on the 
characteristics of rebel groups. The unit of analysis in these data is a conflict-dyad-period, i.e., a government is combined with a rebel group in one period of time (of any length) in which the attributes of this conflict dyad do not change. As soon as there is a change in any of the dyad's parameters, however, a new observation is given in the data.

Conflicts in the NSA data are a somewhat heterogeneous sample as the data include extreme cases like civil wars, but also terrorist-driven disputes of a smaller scale. Note further that one conflict may have more than one rebel organization fighting against governmental forces and, hence, each separate rebel group forms a conflict dyad with the government. We use version 3.3 of the data, which comprises 248 unique rebel groups and 295 conflict-dyadperiods between 1989 and 2010. In order to address potential intra-group dependencies across the conflict-dyad-periods, we cluster the standard errors of our upcoming models' covariates on government-rebel dyads. ${ }^{6}$

\section{Dependent Variable: The Fighting Capacity of Rebel Groups}

As described above, we understand a rebel group's military effectiveness as its fighting capacity, i.e., the ability to employ its forces to destroy the government's military while preserving its own troops - holding situational or environmental factors, force size, and weapon technology constant (Dupuy 1992: 71ff; Pollack 2002: 10; Biddle 2004: 6; Stanley and Brooks 2007). Two crucial implications follow from this. First, fighting capacity is a dyadic concept, i.e., it can only be assessed in relation to the opponent (see also Pollack 2002: 10). Second, fighting capacity is related to, but conceptually distinct from victory and defeat on the battlefield. A rebel group might have a high fighting capacity, but still lose battles, operations, or entire campaigns (Millet, Murray, and Watman 1988: 3; Pollack 2002: 4).

We use the FIGHTCAP variable from the NSA data in order to measure a rebel group's fighting capacity relative to the government (Cunningham, Gleditsch, and Salehyan 2009). This variable measures the fighting capacity of a rebel group relative to the government on a three-point scale: low $(N=193)$, moderate $(N=84)$, and high $(N=8)$. However, the original data only contain eight observations for the "high fighting capacity" category, meaning that these observations could belong to an outlier category that might overestimate our results. Therefore, we recoded FIGHTCAP by grouping the "moderate" and "high" categories together. Our final dependent variable FIGHTING CAPACITY then constitutes a less

\footnotetext{
${ }^{6}$ We refer the reader to Cunningham, Gleditsch, and Salehyan $(2009 ; 2013)$ and the data's codebook and case description files for a more detailed description of the data that are available at: http://privatewww.essex.ac.uk/ ksg/eacd.html. Note that personal communication with the authors of the NSA revealed that fighting capacity is not coded based on the use of child soldiers (we discuss this variable below).
} 
stratified, i.e., binary item that receives the value of 1 for moderate to high fighting capacities of rebels relative to the government $(N=92)$ and the value of 0 for a rebel group's low fighting capacity relative to governmental forces $(N=193)$.

\section{Core Explanatory Variable: Child Soldiers in Rebel Groups}

It is generally hard to obtain accurate data on child soldier usage (Tynes 2011: 2; Brett and McCallin 1996; Høiskar 2001), and thus there are only a few systematic cross-sectional data compilations on child soldiers. Acvarina and Reich (2006; 2010), for instance, estimate the percentage of children used at the macro level, i.e., in an armed conflict per conflict-country. However, the arguably most prominent and comprehensive datasets that record the number of children used per armed group ("micro level") are compiled by Beber and Blattman (2013) and Tynes (2011). ${ }^{7}$ First, Beber and Blattman (2013) categorize the percentage share of child soldiers in 40 randomly selected Sub-Saharan African armed groups. ${ }^{8}$ Second, Tynes (2011) recorded a dichotomous indicator on the use of child soldiers by 198 armed groups between 1987 and 2007 (see also Tynes and Early 2011). ${ }^{9}$

Our data collection sought to combine the strengths of both datasets by trying to compile data that go beyond a binary variable measuring child soldier usage, while ensuring a comprehensive coverage of rebel groups worldwide. We, therefore, constructed a variable capturing the use of child soldiers, defined as any person below 18 years of age who has been recruited or used by an armed group as a soldier (UNICEF 2007), for each of the NSA data's conflict-dyad-periods in 1989-2010 on a three-point scale: a conflict-dyad-period in which the rebel group did not use child soldiers at all (coded as 0 ), a conflict-dyad-period in which the rebel group used a few child soldiers, i.e., less than 50 percent of the overall group size (coded as 1), and a conflict-dyad-period in which the rebel group used many child soldiers, i.e., more than 50 percent of the group size (coded as 2). The coding of this ordinal variable is based on independent reports from inter alia Child Soldiers International (formerly known as the Coalition to Stop the Use of Child Soldiers), Human Rights Watch, Amnesty International, Global March against Child Labor, and various independent news and academic sources in different languages (English, German, French, and Spanish). The supplementary material (Appendix II) describes these data and the coding decisions in detail.

\footnotetext{
${ }^{7}$ Another noteworthy dataset is provided by Lasley and Thyne (2014). The time period covered by these authors is only 1998-2008, however. In addition, while their replication material is available online (http://www.uky.edu/ clthyn2/research.htm), the data file lacks a temporal ID variable, which makes the comparison with other datasets rather difficult.

${ }^{8}$ Beber and Blattman's (2013) data can be accessed at: http://chrisblattman.com/projects/sway/.

${ }^{9}$ Tynes's (2011) data is listed in the appendix of his doctoral dissertation.
} 
Figure 1

To illustrate the coding of our variable more thoroughly, 75 rebel groups (i.e., 25.51 percent of all conflict-dyad-periods in our sample) did not recruit any child soldiers at all between 1989 and 2010. For instance, we did not find any official reports indicating that the Ethiopian People's Revolutionary Democratic Front, the Algerian group Exile and Redemption, or the Turkish Maoist Communist Party relied on adolescent soldiers. Moreover, 165 rebel groups (i.e., 56.12 percent of our sample) used some child soldiers, and 54 groups (18.37 percent of our sample) are characterized in particular conflict-dyad-periods by using many child soldiers, i.e., more than 50 percent of a rebel group was comprised of child soldiers in the time period for which we collected the data. For instance, the reports we used for the coding show that the Revolutionary United Front (RUF), once active in Sierra Leone, recruited children on a very large scale. The same holds for the Communist Party of Nepal (Maoist). Figure 1 gives an overview of the countries in which rebel groups operated that relied on child soldering according to our data.

Table 1

Table 1 summarizes the frequency of observations for the values of our dependent variable (FIGHTING CAPACITY) along the categories of CHILD SOLDIERS. The table shows that most groups did employ some child soldiers, but had a rather low military effectiveness (118 groups). The People's War Group in India, for instance, employed some children to provide food and to deliver ransom notes, but had a low fighting capacity compared to the Indian government. Table 1 also shows that few groups did not recruit any child soldiers at all, but had a high fighting capacity ( 24 groups). For example, there is no evidence that the military faction of Hugo Chávez active in Venezuela in 1992 used children, although they had a high fighting capacity according to the NSA data. Most crucially, though, the table demonstrates that there are in fact groups that employed many child soldiers (coded as 2) and did have a high fighting capacity. The LRA (active in Uganda) that used children as active combatants is an illustrative case for this. In addition, some groups having a high level of fighting capacity employed children in supportive functions. For example, the Mexican Zapatista National Liberation Army (EZLN) is known to have employed child soldiers in especially supportive groups ("bases de apoyo"), while having a high level of fighting capacity compared to the 
Mexican government. Some Cambodian rebel groups such as the Khmer Rouge, Khmer People's National Liberation Front, and the Front Uni National pour un Cambodge Indépendant, Neutre, Pacifique, et Coopératif (FUNCINPEC) are similarly characterized (Seaman 1999: 6). ${ }^{10}$ While a clear relationship between the fighting capacity and child recruitment cannot be identified based on Table 1, the Pearson $\chi^{2}$ test indicates that the two items are indeed related to each other. Yet, a more systematic analysis is required that also takes into account several potential other determinants of rebel's fighting capacity or child soldier recruitment.

\section{Control Variables}

We control for other potential alternative explanations that have been identified as crucial influences of either fighting capacity (see, e.g., Dupuy 1992: 71ff; Biddle 2004: 6; Stanley and Brooks 2007) or child soldier recruitment (see, e.g., Honawa 2006; Singer 2006; Beber and Blattman 2010). The variables for the latter are particularly important for our empirical models in light of a "selection on observables." Moreover, these "child soldier recruitment variables" primarily pertain to the demand side of child soldering, although some of them may also be listed under the supply side (e.g., RESOURCES) or are more general systemic factors (e.g., ARMS PROCUREMENT). Finally, with regard to the determinants of rebel groups' fighting capacities, i.e., situational or environmental factors, force size, and weapon technology (Dupuy 1992: 71ff; Biddle 2004: 6; Stanley and Brooks 2007), we closely follow Cunningham, Gleditsch, and Salehyan's (2009: 580) variables that capture "the ability of a rebel group to target the government with military force."

First, there is STRENGTH CENTRAL COMMAND that measures the extent to which a central command exercises control over the constituent groups of an insurgent movement. According to Cunningham, Gleditsch, and Salehyan (2009: 580), "a strong central command provides the organizational structure necessary to mount an effective rebel strategy against the state [...]." We employ an ordinal variable that ranges in $[1 ; 3]$ : lower values signify no or only a weak central command structure, while higher values stand for stronger command structures of rebel forces, which is likely to influence their fighting capacity. We expect this variable to positively influence rebels' fighting capacity.

\footnotetext{
${ }^{10}$ Appendix II lists several other case illustreations.

${ }^{11}$ The supplementary material describes robustness checks that move beyond using group-level variables such as a country's regime type or GDP per capita (state capacity) in order to rule out that, e.g., the identified correlation between child soldering and rebel fighting capacity is simply picking up or driven by some third factor. Moreover, we also estimated bivariate probit models that may account for the non-random selection of child soldiers. The results of these models do not differ much from the findings presented here.
} 
Second, we consider a dichotomous variable for a rebel group's mobilization capacity. When subscribing to the assumption that child and adult soldiers are complements rather than substitutes, rebel groups that have the ability to recruit a larger number of fighters are not only more likely to draft child soldiers, but also "present a clear threat to governments and engage in direct attacks" (Cunningham, Gleditsch, and Salehyan 2009: 580). In other words, we assume that the higher their mobility capacity is the more likely they are military effective. According to this variable, about 40 percent of our observations have such a mobilization capacity (relative to the government).

Third, Cunningham, Gleditsch, and Salehyan (2009: 580) suggest that "insurgents that have high capacity to procure arms should be better able to effectively target governments." We, therefore, also incorporate their ARMS PROCUREMENT variable, which is a binary item receiving the value of 1 if a rebel group has the ability to procure arms relative to the government and 0 otherwise. Accordingly, this variable captures the argument that technology developments positively influence military organizations' fighting capacities (Millet, Murray, and Watman 1988; Dupuy 1992; Biddle 2004) and controls for Singer's claim $(2006$; 2010) that technological and efficiency advances for weapons affect the recruitment of child soldiers.

Fourth, another dichotomous variable measures whether a rebel group controls any territory (1) or not (0). Having a territory provides rebels with a variety of valuable resources and shelter from the government's authorities seeking to disrupt their position, which is likely to increase rebels' fighting capacity (e.g., Asal and Rethemeyer 2008). Territorial control also facilitates to accommodate training complexes, arms depots, etc., and may make it easier to draft adolescent fighters.

Fifth, the military effectiveness literature highlights the importance of force size (e.g., Millet, Murray, and Watman 1986; 1988; Dupuy 1992; Biddle 2004; Stanley and Brooks 2007). The larger the size of a rebel group, the more likely it is comprised of people skilled at fighting and strategy/tactics. That said, it could also be the case that the more people are being recruited, the less developed or advanced their training and equipment may be. Either way, in order to control for these possible influence, we include the NSA's estimate of each rebel group's size per conflict dyad (Cunningham, Gleditsch, and Salehyan 2009). This measures ranges from 100 (i.e., the National Democratic Front of Bodoland in India) to 160,000 (i.e., the Armenian National Movement in 1990). We use the dataset's "best estimate of the size of rebel armed forces," and take the natural logarithm to account for the skewed distribution of this item. 
Sixth, the duration of a conflict can have a major impact on the fighting capacity of rebel organizations. Commonly referred to as a situational or environmental factor in the literature (Dupuy 1992: 71ff; Biddle 2004: 6), one argument states that the longer the duration of a conflict, the higher the likelihood that the fighting capacity of rebel groups increases due to organizational learning (see, e.g., Asal and Rethemeyer 2008). In addition, the longer the duration of a conflict-dyad-period, the higher the chances children have been recruited as fighters (Tynes and Early 2011: 19). To control for these mechanisms, we include a count variable measuring the time (in years) elapsed since the start of a conflict-dyad-period until its end; this item is based on the Uppsala Armed Conflict Data (Gleditsch et al. 2002). Note that this variable also controls for any remaining temporal dependencies in the data as it captures the length of a conflict-dyad-period. ${ }^{12}$

Seventh, rebels' fighting capacity and their ability to recruit child soldiers may be determined by the wealth of a particular armed group (see, e.g., Dallaire 2011). More affluent rebel organizations are better able to acquire weapons or invest more into military training. In other words, it is highly likely that wealthier rebel groups are the ones most military effective. While there are no accurate data on the financial track record of armed groups, we include a variable that measures the presence of several resources in the country in which an armed group is based. To this end, we use information from Buhaug and Lujala (2005), Gilmore et al. (2005), Lujala et al. (2007), and Lujala (2009) on the presence of drugs, petroleum, diamonds, and gemstones in a country. On the basis of this information, we constructed an additive variable ranging from 0 to 4: higher values stand for the presence of more resources in the state in which the rebel group is active.

Finally, the literature on child soldering shows that conflict type matters (Lasley and Thynes 2014) and predominantly rebel organizations in civil wars have recruited children (Gates and Reich 2010). Our last control variable thus captures in a dichotomous fashion whether the conflict of each conflict-dyad-period pertains to a civil war (1), as defined by the Uppsala Armed Conflict Data (Gleditsch et al. 2002), or not (0).

Table 2 summarizes the descriptive statistics and variation inflation factors (VIFs) of our variables. All explanatory variables are well below the used threshold level of 5, indicating that there is not much overlap or correlation between any of them.

\footnotetext{
${ }^{12}$ That being said, note that conflict duration might be endogenous to rebel fighting capacity. For example, if rebels are weak, government forces might defeat them more quickly, leading to shorter conflict duration. Our results remain, however, virtually the same when leaving out this item from our model (Table 3 and Appendix I).
} 
Table 2

\section{Empirical Results}

Due to our dichotomous dependent variable, we use probit regression models to analyze the data. Table 3 shows our results. Model 1 only considers our core explanatory variable and those control variables that are seen as important drivers of rebel groups' fighting capacities according to Cunningham, Gleditsch, and Salehyan (2009). Model 2 incorporates all explanatory variables we discussed in the previous section. In addition, Figure 2 graphs the substantive quantities of interest, i.e., first difference estimates. A first difference estimate captures the change in the predicted probability (in the form of percentage points) of observing an outcome (i.e., $y=1$ ) as a given explanatory variable changes values from its minimum to its maximum, while all other explanatory variables are held constant at their medians (King, Tomz, and Wittenberg 2000).

Table 3 and Figure 2

Regardless of our model specifications, CHILD SOLDIERS has a positive and statistically significant impact on rebel groups' fighting capacities. Hence, it seems that the recruitment of children does in fact increase the fighting capacity of a rebel group. The first difference point estimate of this item is at 0.11 on average throughout Models 1-2: when raising CHILD SOLDIERS from its minimum to its maximum, the probability of a moderate to high fighting capacity increases on average by 11 percentage points. In other words, child soldier recruitment actually does make rebel groups more militarily effective and increases their chances to successfully fight against governmental troops. This finding is robust across several models specifications; adding or dropping control covariates does not affect its substance. ${ }^{13}$ The results of our analysis are therefore the first indication that the recruitment of children might indeed increase the fighting capacity of a rebel group (e.g., Honawa 2006; Singer 2006; 2010; Beber and Blattman 2013; Tynes 2011; Tynes and Early 2011).

\footnotetext{
${ }^{13}$ Note that we also tested for a curvilinear impact of CHILD SOLDIERS on our dependent variable. The square term of CHILD SOLDIERS that we added to our models did not achieve conventional levels of significance in any estimation, though.
} 
Coming to the control covariates in our models, their impact and substance do essentially not change over the model estimations. Most variables mirror existing findings or arguments in the literature (e.g., Honawa 2006; Singer 2006; 2010; Beber and Blattman 2013; Tynes 2011; Tynes and Early 2011; Dupuy 1992: 71ff; Biddle 2004: 6; Pollack 2002: 10; Stanley and Brooks 2007) and we only discuss the statistically significant items. First, next to REBEL GROUP SIZE (ln), ARMS PROCUREMENT is one of the strongest determinants. This supports Cunningham, Gleditsch, and Salehyan (2009) who argue that group size and skillful arms procurement positively influence a rebel group's fighting capacity (see also Millet, Murray and Watman 1988; Dupuy 1992; Biddle 2004).

Second, the more resources are available in a country, the more likely it is that rebels can exploit them (Fearon and Laitin 2003; Koubi et al. 2014). Our results support these claims as RESOURCES has a positive and statistically significant impact. The point estimates for this variable's first differences suggest an increase in a rebel group's fighting capacity by 26 percentage points on average.

Third, Asal and Rethemeyer (2008), for instance, argue that the longer the duration of a conflict, the higher the likelihood that the fighting capacity of rebel groups increases due to organizational learning. Our findings cannot support this claim. On average, the probability of a moderate to high fighting capacity decreases by 11 percentage points when DURATION is moved from its minimum toward its maximum. Hence, our models actually suggest that the longer a conflict, the higher the likelihood that a conflict cycle escalated, which weakens the rebels (e.g., Cunningham, Gleditsch, and Salehyan 2009).

Fourth, the CIVIL WAR dummy has a statistically and significant effect on the fighting capacity of rebel groups. In other words, non-sate actors involved in a civil war are more likely to have a higher fighting capacity than those who are involved in short term actions like terrorist-driven disputes.

Fifth, the analyses also highlight that DURATION and RESOURCES display a statistically significant and positive impact on the likelihood of child recruitment. The longer the duration of a conflict-dyad-period, the higher the chances children have been recruited (Tynes and Early 2011: 19). Moreover, rebels' ability to recruit child soldiers may be determined by resources, which can also be seen as a supply-side determinant (Tynes 2011: 93).

Against this background, it is worth noting that the control items RESOURCES and ARMS PROCUREMENT seem to have a much stronger impact on FIGHTING CAPACITY than CHILD SOLDIERS. On average, ARMS PROCUREMENT has a higher impact than 
CHILD SOLDIERS by about 90 percentage points, while RESOURCES scores better by about 13 percentage points than our core variable of interest. Hence, although we could demonstrate that child soldiering does influence a rebel group's fighting capacity and that it does so positively and significantly, RESOURCES and ARMS PROCUREMENT seem to be more important determinants. We return to this point in the conclusion now.

\section{Conclusion}

The academic discussion on child soldiers in armed conflicts primarily focused so far on those factors that may make it more likely that children are recruited as fighters or join armed groups. Only a few studies examined what kind of consequences this might have for armed groups' fighting capacity. The existing literature did not systematically try to answer this question empirically, and, in fact, seemed to simply rely on the assumption that children possess particular characteristics, which make them as military effective as (or even more effective than) adult combatants - or militarily weaker. Based on a newly compiled dataset on child soldier recruitment by rebel groups between 1989 and 2010, we analyzed the relationship between these groups' fighting capacities and the involvement of adolescent fighters. The results demonstrate that child soldiers are indeed more likely to be associated with higher fighting capacities of rebel groups. However, when taking into account our control variables as well, we found support that rebels' ability to procure arms and the access to resources are more important influences.

Our findings are not necessarily counterintuitive given the various presented arguments for why child soldiers might be militarily effective. That said, it is important to note that although there might be "benefits" associated with child soldiering, our research should not be seen as endorsing the use of child soldiers by rebel groups. Instead, it is meant to help decision-makers, international organizations, and human-rights groups to understand the persistence of child soldering among rebel groups with a view toward the development of more effective strategies to abolish the use of children in conflicts.

Our work therefore highlights, for example, that the international community should realize that recruiting and using children during battles is not just an immoral strategy, but can in fact positively affect rebels' fighting capacities. This does certainly not make the aim of abolishing child soldering easier, as activists may be ill-advised to try to dissuade child soldering on tactical grounds. Hence, governments and activists should rather rely on other, more enforcing ways that can change rebels' cost-benefit analysis more substantially. For instance, economic sanctions or counter-propaganda strategies can be considered as a 
worthwhile tool in order to enforce compliance with international law (e.g., Keen 2008; Beber and Blattman 2010).

Moreover, our work emphasized in line with existing research (e.g., Cunningham, Gleditsch, and Salehyan 2009) that other factors also matter for rebels' fighting capacity, and arguably even more so than child soldiering. The variables on arms procurement and the presence of resources are the most prominent examples here. Thus, our evidence for the impact of these key determinants further increases our understanding of rebel groups, how they operate, and what they rely on, and, more generally perhaps, our knowledge on the factors leading to conflict onset, duration, and outcomes.

While it is our hope that we could shed light on the relationship between child soldier recruitment and the military effectiveness of armed groups, one study is insufficient to address this important issue comprehensively. Many questions remain and multiple avenues for further research do exist. First, although we identified a positive correlation between child soldiering and rebel groups' fighting capacities, we could not evaluate the relative impact of child soldiers in light of the potential costs that are associated with this. Rebels still have to invest resources for children's military training and socialization. Given that the necessary investment efforts for these processes are potentially costly, child recruitment could well be an inefficient strategy: the costs associated with child soldering in the first place may outweigh the benefits of an increase in rebel groups' fighting capacity. However, our research focused on the estimation of benefits with the analysis of costs left aside. Consequently, it remains unclear (1) what kinds of costs are associated with child soldiering, and (2) whether these costs outweigh (or not) the benefits. In light of this, there also seems to be a need for systematic micro-level studies on the causal mechanisms behind the decision to use child soldiers or not.

Second, the child soldier usage variable we employed is of ordinal nature, but more accurate measures - also for other military organizations such as governments' military could be constructed. Similarly, and in light of the costs of child soldering that might be associated with socialization and training processes, the threshold value for child soldiers at 18 years of age might be problematic. Identity formation for a 17-year old is much more concretized than for a 15 or 14-year old (see Erikson 1995). Moreover, while 14-year olds could be easily socialized, 17-year olds might be more obstinate. The under-18 threshold does not address this variation and, in fact, the coefficient on child recruitment may then be biased toward zero, since it averages groups that recruit a few older teenagers with groups that recruit large numbers of, say, 12-year olds. Alternative data definitions, which rely on 
more accurate and disaggregated data, might find stronger results. However, additional data compilation efforts are necessary here.

Finally, our work focused on the demand side of child soldering and, specifically, the fighting capacity of rebel groups. However, a more systematic analysis of supply-side influences and also other aspects besides fighting capacity on the demand side seems to be in need. 
Table 1. FIGHTING CAPACITY and CHILD SOLDIERS - Contingency Table CHILD SOLDIERS

\begin{tabular}{c|ccc|c} 
FIGHTING CAPACITY & 0 & 1 & 2 & Total \\
\hline 0 & $47(24.35)$ & $118(61.14)$ & $28(14.51)$ & $193(100)$ \\
1 & $24(26.37)$ & $43(47.25)$ & $24(26.37)$ & $91(100)$ \\
\hline Total & $71(25.00)$ & $161(56.69)$ & $52(18.31)$ & $284(100)$
\end{tabular}

Note: Table entries are counts, with percentages out of row totals in parentheses. 
Table 2. Overview of Variables

\begin{tabular}{lcccccc}
\hline \multicolumn{1}{c}{ Variable } & Obs. & Mean & Std. & Min & Max & VIF \\
\hline FIGHTING CAPACITY & 285 & 0.32 & 0.47 & 0 & 1 & \\
CHILD SOLDIERS & 294 & 0.93 & 0.66 & 0 & 2 & 1.10 \\
STRENGTH CENTRAL COMMAND & 275 & 1.99 & 0.66 & 1 & 3 & 1.16 \\
MOBILIZATION CAPACITY & 284 & 0.40 & 0.49 & 0 & 1 & 1.35 \\
ARMS PROCUREMENT & 276 & 1.31 & 0.49 & 1 & 3 & 1.42 \\
TERRITORIAL CONTROL & 293 & 0.35 & 0.48 & 0 & 1 & 1.34 \\
REBEL GROUP SIZE (ln) & 249 & 8.08 & 1.58 & 4.61 & 11.98 & 1.58 \\
DURATION & 295 & 4.30 & 6.04 & 0 & 42 & 1.15 \\
RESOURCES & 295 & 2.11 & 1.12 & 0 & 4 & 1.13 \\
CIVIL WAR DUMMY & 287 & 0.47 & 0.50 & 0 & 1 & 1.17 \\
\hline
\end{tabular}


Table 3. The Determinants of Rebel Groups' Fighting Capacity

\begin{tabular}{lcc}
\hline & Model 1 & Model 2 \\
\hline CHILD SOLDIERS & 0.36 & 0.40 \\
& $(0.16)^{* *}$ & $(0.23)^{*}$ \\
STRENGTH CENTRAL & 0.18 & 0.11 \\
& $(0.18)$ & $(0.22)$ \\
MOBILIZATION CAPACITY & 0.19 & 0.22 \\
& $(0.21)$ & $(0.28)$ \\
ARMS PROCUREMENT & 2.45 & 2.50 \\
TERRITORIAL CONTROL & $(0.26)^{* * *}$ & $(0.32)^{* * *}$ \\
& -0.13 & 0.09 \\
REBEL GROUP SIZE (ln) & $(0.22)$ & $(0.27)$ \\
& & 0.23 \\
DURATION & & $(0.10)^{* *}$ \\
& & -0.09 \\
RESOURCES & & $(0.04)^{* *}$ \\
CIVIL WAR DUMMY & & 0.46 \\
& & $(0.14)^{* * *}$ \\
CONSTANT & & 0.73 \\
& $(0.29)^{* *}$ \\
Observations & -4.60 & -7.59 \\
Log Pseudolikelihood & $(0.51)^{* * *}$ & $(1.19)^{* * *}$ \\
Wald $\chi^{2}$ & 264 & 224 \\
& -80.31 & -53.44 \\
& $100.69 * * *$ & $84.37 * * *$ \\
\hline
\end{tabular}

Note: Table entries are coefficients from probit regression models; clustered robust standard errors in parentheses; * significant at 10 percent; ** significant at 5 percent; *** significant at 1 percent (two-tailed). 


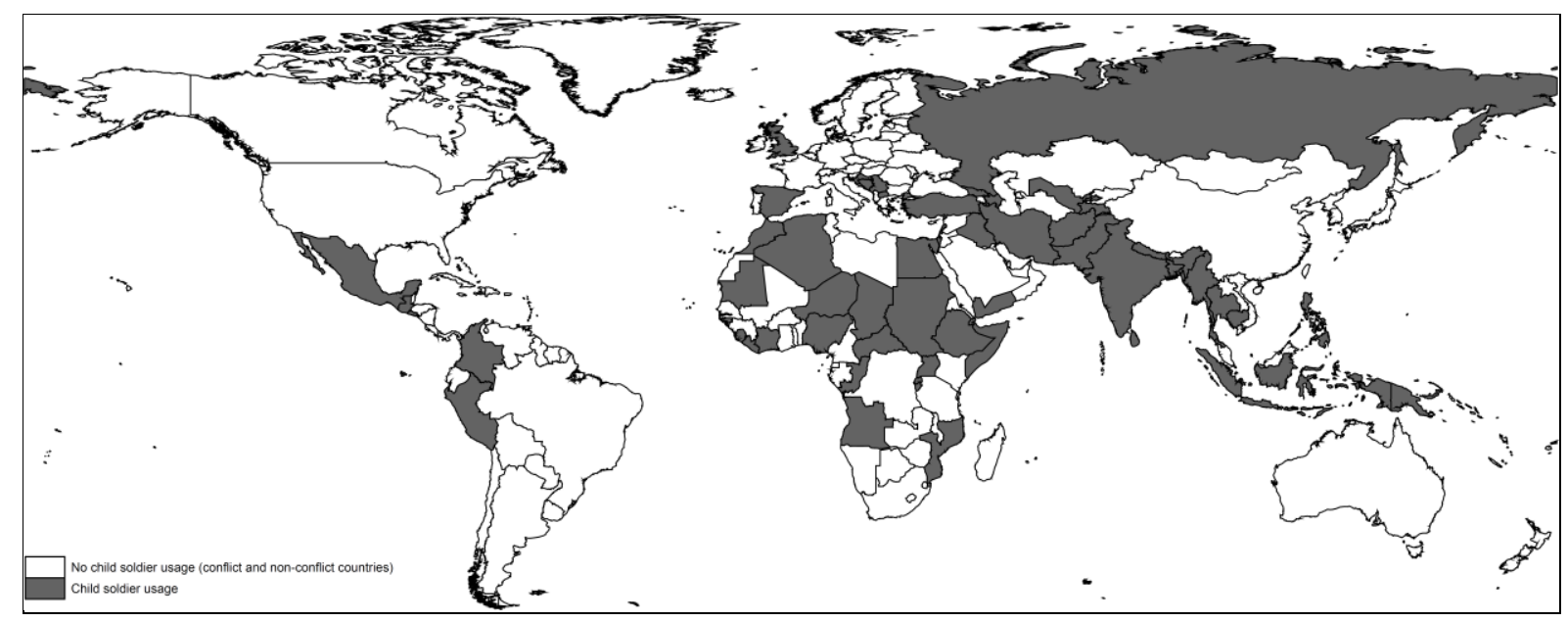

Figure 1. The Usage of Child Soldiers Worldwide, 1989-2010

Note: Shaded countries signify states in which at least one rebel group used child soldiers during conflict. White marked countries are non-conflict states or rebel groups without child soldiers operated. 


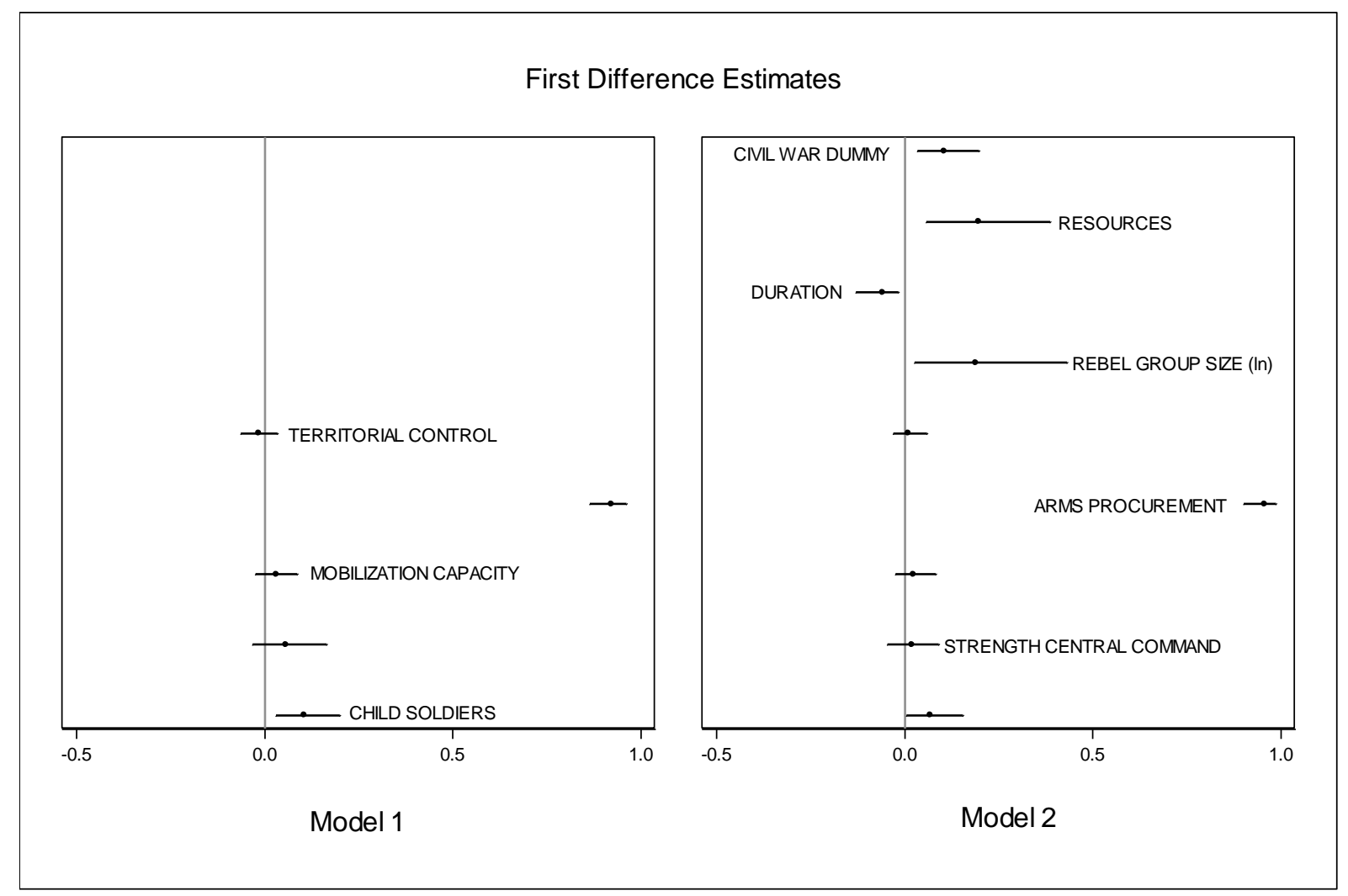

Figure 2. The Impact on Rebel Groups' Fighting Capacity: First Differences

Note: Simulated estimates are based on 1,000 draws from a multivariate normal distribution. Horizontal bars pertain to 90 percent confidence intervals. First difference estimate of 0 marked with vertical grey line. Variable labels given in one panel only to facilitate readability, but are identical across panels. 


\section{References}

Achvarina, Vera, and Simon Reich. (2006) No place to hide: Refugees, displaced persons, and the recruitment of child soldiers. International Security 31 (1): 127-164.

Achvarina, Vera, and Simon Reich. (2010) No place to hide: Refugees, displaced persons, and child soldier recruits. In: Scott Gates and Simon Reich (eds.). Child soldiers in the age of fractured states. Pittsburgh, PA: University of Pittsburg Press, 55-76.

Andvig, Jens Christopher, and Scott Gates. (2010) Recruiting children for armed conflict. In: Scott Gates and Simon Reich (eds.). Child soldiers in the age of fractured states. Pittsburgh, PA: University of Pittsburg Press, 77-92.

Asal, Victor, and Karl Rethemeyer. (2008) The nature of the beast: Organizational structures and the lethality of terrorist attacks. Journal of Politics 70 (2): 437-449.

Beber, Bernd, and Christopher Blattman. (2010) The industrial organization of rebellion: The logic of forced labor and child soldiering. New York University: Typescript. Available online at: http://www.gwu.edu/ igis/assets/docs/Blattman_Paper.pdf.

Beber, Bernd, and Christopher Blattman. (2013) The logic of child soldiering and coercion. International Organization 67 (1): 65-104.

Biddle, Stephen. (2004) Military power: Explaining victory and defeat in modern battle. Princeton, NJ: Princeton.

Biddle, Stephen, and Stephen Long (2004) Democracy and military effectiveness: A deeper look. Journal of Conflict Resolution 48 (4): 525-546.

Biddle, Stephen, and Stephen Long. (2004) Democracy and military effectiveness. Journal of Conflict Resolution 48 (4): 525-546.

Brett, Rachel, Margaret McCallin, and Rhona O'Shea. (1996) Children: Invisible soldiers. Report on the participation of children in armed conflicts and international disturbances and tensions for the United Nation Study in the impact of armed conflict on children. Geneva: The Quaker United Nations Office.

Brett, Rachel, and Margaret McCallin. (1998) Children: The invisible soldiers. Rädda Barnen (Swedish: Save the Children): Stockholm.

Brett, Rachel, and Irma Specht. (2004) Young soldiers: Why they choose to fight. Boulder, CO: Lynne Rienner.

Brooks, Risa (2003) Conceptualizing military effectiveness. Unpublished manuscript.

Buhaug, Halvard, and Päivi Lujala. (2005) Accounting for scale: Measuring geography in quantitative studies of civil war. Political Geography 24 (4): 399-418. 
Coalition to Stop the Use of Child Soldiers. (2010) Briefing paper Democratic Republic of Congo. Mai Mai child soldier recruitment and use: Entrenched and unending. London: Coalition to Stop the Use of Child Soldiers.

Cohn, Ilene, and Guy Goodwin-Gill (2003) Child soldiers. The role of children in armed conflict. Oxford: Clarendon Press.

Cunningham, David, Kristian Skrede Gleditsch, and Idean Salehyan. (2009) It takes two: A dyadic analysis of civil war duration and outcome. Journal of Conflict Resolution 53 (4): 570-597.

Cunningham, David, Kristian Skrede Gleditsch, and Idean Salehyan. (2013) Non-state actors in civil wars: A new dataset. Conflict Management and Peace Science 30 (5): 516-531.

Dallaire, Roméo A. 2011. They fight like soldiers, they die like children: The global quest to eradicate the use of child soldiers. New York: Walker and Company.

Desch, Michael C. (2008) Power and military effectiveness: The fallacy of democratic triumphalism. Baltimore, MA: Johns Hopkins University Press.

Dickson-Gõmez, Julia. (2002) Growing up in guerrilla camp: The long-term impact of being a child soldier in El Salvador's civil war. Ethos 30 (4): 327-356.

Dupuy, Trevor. (1992) Understanding war: History and theory of combat. London: Leo Cooper.

English, John A., and Bruce I. Gudmundsson (1994) On infantry. London: Praeger.

Erikson, Erik. (1995) Identity: Youth and Crisis. New York: W. W. Norton \& Company.

Fearon, James, and David Laitin. (2003) Ethnicity, insurgency, and civil war. American Political Science Review 97 (1): 75-90.

Gates, Scott. (2011) Why do children fight? Motivations and the mode of recruitment. In: Alpaslan Özerdem and Sukanya Podder (eds.). Child soldiers: From recruitment to reintegration. New York: Palgrave Macmillan, 29-49.

Gates, Scott; Håvard Hegre, and Håvard Strand. (2007) Global trends in armed conflict. Oslo: Peace Research Institute.

Gates, Scott, and Simon Reich. (2010) Introduction. In: Scott Gates and Simon Reich (eds.). Child soldiers in the age of fractured states. Pittsburgh, PA: University of Pittsburg Press, $3-13$.

Gilmore, Elisabeth, Nils Petter Gleditsch, Päivi Lujala, and Jan Ketil Rød. (2005) Conflict diamonds: A new dataset. Conflict Management and Peace Science 22 (3): 257-92. 
Gleditsch, Nils Petter, Peter Wallensteen, Mikael Eriksson, Margareta Sollenberg, and Håvard Strand. (2002) Armed conflict 1946-2001: A new dataset. Journal of Peace Research 39 (5): 615-637.

Gutiérrez Sanín, Francisco. (2010) Organizing minors - The case of Colombia. In: Scott Gates and Simon Reich (eds.). Child soldiers in the age of fractured states. Pittsburgh, PA: University of Pittsburg Press, 121-142.

Hazen, Jennifer M. (2005) Social integration of ex-Combatants after civil war. Division social policy and development (DESA), United Nations. Expert group meeting in dialogue in the social integration process. Available online at: http://www.un.org/esa/socdev/sib/egm/ paper/Jennifer\%20Hazen.pdf.

Hecker, Tobias \& Roos Haer (forthcoming) Drugs boosting conflict? A micro-level test of the linkage between substance use and violence. Terrorism and Political Violence.

Hecker, Tobias; Katharin Hermenau, Anna Maedl, Harald Hinkel, Maggie Schauer \& Thomas Elbert (2013) Does perpetrating violence damage mental health? Differences between forcibly recruited and voluntary combatants in DR Congo. Journal of Traumatic Stress 26(1): 142-48.

Høiskar, Astr Halsan. (2001) Underage and under fire. An enquiry into the use of child soldiers 1994-8. Childhood 8 (3): 340-360.

Honwana, Alcinda. (2006) Child soldiers in Africa. Philadelphia, PA: University of Pennsylvania Press.

Human Rights Watch. (2003) "You'll Learn Not to Cry." Child Combatants in Colombia. Human Rights Watch: New York.

Human Security Report. (2005) War and Peace in the 21st Century. Human Security Centre: The University of British Colombia, Canada.

Images Asia. (1997) No childhood at all - Child soldiers in Burma. Chiangmai: Nopburee Press.

International Labor Office. (2003) Wounded childhood: The use of children in armed conflict in Central Africa. International Labor Office: Geneva.

IRIN. (2003) Liberia: Release child soldiers, UNICEF tells fighting groups. Available online at: $\quad$ http://www.irinnews.org/report/46634/liberia-release-child-soldiers-unicef-tellsfighting-groups.

Junger, Sebastian. (2000) Terror Recorded. Vanity Fair 482: 366-369.

Kaplan, Eben (2005) Child Soldiers around the World. Washington, DC: Council on Foreign Relations. 
Keen, David. (2008) Complex emergencies. Cambridge: Polity Press.

King, Gary; Michael Tomz, and Jason Wittenberg. (2000) Making the most of statistical analyses: Improving interpretation and presentation. American Journal of Political Science 44 (2): 347-361.

Koubi, Vally, Gabriele Spilker, Tobias Böhmelt, and Thomas Bernauer. (2014). Do natural resources matter for inter- and intrastate armed conflict? Journal of Peace Research 51 (2): Forthcoming.

Lasley, Trace, and Clayton Thyne. (2014) Secession, Legitimacy, and the Use of Child Soldiers. Conflict Management and Peace Science: Forthcoming.

London, Charles. (2007) One day the soldiers came. Voices of children in war. New York: Harper Perennial.

Lujala, Päivi, Jan Ketil Rød, and Nadia Thieme. (2007) Fighting over oil: Introducing a new dataset. Conflict Management and Peace Science 24 (3): 239-56.

Lujala, Päivi. (2009) Deadly combat over natural resources: Gems, petroleum, drugs, and the severity of armed civil conflict. Journal of Conflict Resolution 53 (1): 50-71.

Millet, Allan, Williamson Murray, and Kenneth Watman. (1986) The effectiveness of military organizations. International Security 11 (1): 37-71.

Millet, Allan, Williamson Murray, and Kenneth Watman. (1988) The effectiveness of military organizations. In: Allan R. Millet and Williamson Murray (eds.). Military effectiveness, volume I: The first world war. Boston, MA: Allen and Unwin, 1-30.

Pollack, Kenneth. (2002) Arabs at war: Military effectiveness, 1948-1991. Lincoln, NE: University of Nebraska Press.

Reiter, Dan, and Allan Stam. (1998). Democracy and battlefield military effectiveness. Journal of Conflict Resolution 42 (3): 259-277.

Reiter, Dan, and Allan Stam. (2002) Democracies at war. Princeton, NJ: Princeton University Press.

Rosen, Stephen Peter (1995) Military effectiveness: Why society matters. International Security 19 (4): 5-31.

Rosen, David M. (2005) Armies of the Young: child soldiers in war and terrorism. New York: Ruthers unviersity Press.

Schauer, Elisabeth, and Thomas Elbert. (2010) The psychological impact of child soldiering. In: Erin Martz (ed.). Trauma rehabilitation after war and conflict. New York: Springer, 311-360. 
Seaman, Tim. (1999) Briefing paper on child soldiers in Cambodia. LICADHO (Cambodian League for Promotion and Defense of Human Rights). Available online via: http://www.licadho-cambodia.org/reports.php?perm=19.

Singer, Peter. (2006) Children at war. Berkeley, CA: University of California Press.

Singer, Peter. (2010) The enablers of war: Causal factors behind the child soldier phenomenon. In: Scott Gates and Simon Reich (eds.). Child soldiers in the age of fractured states. Pittsburgh, PA: University of Pittsburg Press, 93-107.

Stanley, Elizabeth, and Risa Brooks (eds.). (2007) Creating military power: The sources of military effectiveness. Stanford, CA: Stanford University Press.

Talmadge, Caitlin. (2013) The puzzle of personalist performance: Iraqi battlefield effectiveness in the Iran-Iraq war. Security Studies 22 (2): 180-221

Tynes, Robert. (2011) Child soldiers, armed conflicts, and tactical innovations. Dissertation at the University at Albany, State University of New York.

Tynes, Robert, and Bryan Early. (2011) Governments, rebels, and the use of child Soldiers in internal armed conflict. Typescript. Available online at: http://papers.ssrn.com/ sol3/papers.cfm?abstract_id=1898229.

UNICEF. (2002) Adult wars, child soldiers: Voices of children involved in armed conflict in the East Asia and Pacific region. Bangkok: UNICEF (Eastern and Southern Africa regional office).

UNICEF. (2007) The Paris principles. Principles and guidelines on children associated with armed forces or armed groups. Available online at: http://www.unicef.org/emergencies/ files/parisprinciples310107english.pdf.

UN. (2000) Optional protocol to the convention on the rights of the child on the involvement of children in armed conflict. Adopted and opened for signature, ratification and accession by General Assembly resolution A/RES/54/263 of 25 May 2000. Entry in Force 12 February 2002. Available online at: http://www.ohchr.org/EN/Professional Interest/Pages/OPACCRC.aspx.

Vautravers, Alexandre J. (2008) Why child soldiers are such a complex issue. Refugee Survey Quarterly 27 (4): 96-107.

Wessells, Michael. (2006) Child soldiers: From Violence to Protection. Cambridge, MA: Harvard University Press.

Woods, Dorothea. (1993) Child soldiers: The recruitment of children into armed forces and their participation in hostilities. London: Quaker Peace and Service. 